\title{
Study on Application of Design Criteria on the Openstage of Latest Rooms and Displays in Gianyar, Bali
}

\author{
Ida Bagus Gde Wira Krisnha ${ }^{1}$, Syamsul Alam Paturusi ${ }^{2}$, Anak Agung Gde Djaja Bharuna ${ }^{3}$ \\ Bachelor Degree of Architecture Study Program \\ Faculty of Engineering-Udayana University \\ Jimbaran \\ wkgusde@gmail.com \\ Architecture Study Program \\ Faculty of Engineering-Udayana University \\ Jimbaran \\ Architecture Study Program \\ Faculty of Engineering-Udayana University \\ Jimbaran
}

\begin{abstract}
The purpose of Open Stage Anyar in Gianyar is to provide a facility or facilitate activities associated with Balinese tradi-tional performing arts, modern performing arts and various types of performances related to the elements of preserva-tion, development of interests and talents to Balinese arts. Criteria of design to help determine the final outcome of a desired design to match the function of the building. Some things in the review of the Criteria of design which includes layout and appearance of the building. the spatial arrangement shows the results of macro and micro-based analysis of the site and and the activities in it. In terms of appearance the building gives an impression or atmosphere that re-flects local knowledge of an area and can also make people become interested when looking at the view of the build-ing.
\end{abstract}

Index Terms - open stage, arts, performances.

\section{INTRODUCTION}

Bali is a small island located in the Unitary State of the Republic of Indonesia. Bali has a lot of natural charm that is very beautiful and very interesting almost in all remote areas. Bali also has many regional arts that are well-known in all circles of society. Gianyar Regency is one of the 9 regencies in the Province of Bali that is rich in the diversity of arts, customs and culture that is still growing and sustainable to this day, so that the Kabupaen Gianyar Regency is known as the Arts District. Gianyar is an area of art, where in this area has various types of art which is a sacred and traditional dance and many standing art galleries whose numbers recorded to date in Gianyar Regency reached 233 pieces that are scattered in all districts. 23 studios are in Gianyar
Sub-district, 18 studios in Blahbatuh District, 60 studios in Sukawati Sub-district, 20 studios in Tegalalang District, 19 studios in Tampaksiring Sub-district, 76 studios in Ubud Sub-district, and 17 studios in Payangan sub-district [1].

During the period 1942 to 1961 routinely performed by the Barong Dance in the Pura Desa Singapadu which eventually became turmoil over the use of the Pura area as a place to perform the Barong Dance, the artists finally had to create a new staging place in Banjar Sengguan Singapadu. In line with the development of the Barong dance performance which is increasingly widespread and developing rapidly, the development of the stage for the staging in the Sukawati area also developed [2].

The many interests of visitors come to Bali to watch the show, making a lot of the construction of the stage that functioned as a place to watch the show, although the stage used is fairly simple, but it does not dampen the interest of tourists to come see the show that was held. This 
phenomenon is very interesting to be used as a research area with the title "Open Stage Anyar in Gianyar". when it was still in the kingdom system of Gianyar Regency named Griya Anyar, which means Rumah Baru. It is hoped that from this title a magnificent performance venue will be created and does not contain the history of the city of Gianyar itself.

\section{RESUlt AND ANALISYS}

\section{A. Anyar Open Stage}

Anyar Open Stage is a plan that will later be used as a container or place to accommodate various types of arts and performance activities. By seeing the number of tourists visiting Gianyar, especially to Sukawati and Ubud Districts, it is hoped that the (new) Anyar Open Stage planning in Gianyar is intended to realize or revive the interest of tourists to come back to Gianyar Regency to enjoy various types of performances, not only barong performances, but a variety of classical and modern shows with a magnificent container or venue, without forgetting the history of the stage development in Gianyar Regency while enjoying visitors' performances are also presented with enchanting natural scenery.

The location chosen for the construction of the Open Stage is in the Regency of Gianyar, precisely in Kemenuh Village, Sukawati District, Gianyar, this location was chosen because according to the zonazi distribution the Gianyar Sukawati Regency is a center zone for art trade or art development. So when viewed from the zoning area is very appropriate considering the number of Open Stage supporting objects around it.

\section{B. Design Criteria}

Design criteria are a reference in designing. Design criteria as a solution to the problems in the design are then used as design directions that have the results of statements where the statement contains the desired performance. The design criteria include four main things, which are to consider form, function, economy and time. Design criteria aim to determine the description of the desired final design and according to consideration of these four things.

One of the application of design criteria on the appearance of the building by applying elements of Balinese Architecture in the form of the application of Balinese carving ornaments, the Tri Mandala element as a determinant of spatial zones, Asta Kosala Kosali as a determinant of the location of the entrance and the Tri Angga Concept which requires that the final result of the building have elements of head, body and the feet. The architectural elements are the main building constituents which consist of the facade and inner space. The facade is a part of the building that faces the road directly. According to Harimu, the building facade is divided into three main compilers, namely the foot of the building, the building body and the head of the building. For more details, consider the following figures 1 and 2 .

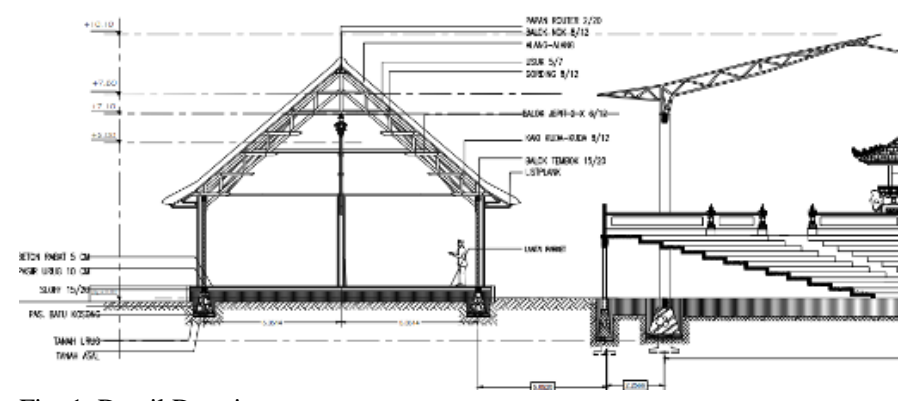

Fig. 1. Detail Drawing

Balinese carvings and ornaments are applied comprehensively in this Open Stage building, can be seen from the entrance to the site, the wall around the site, and of course in all the main buildings and supporting buildings. For more details, consider the following picture 2 .

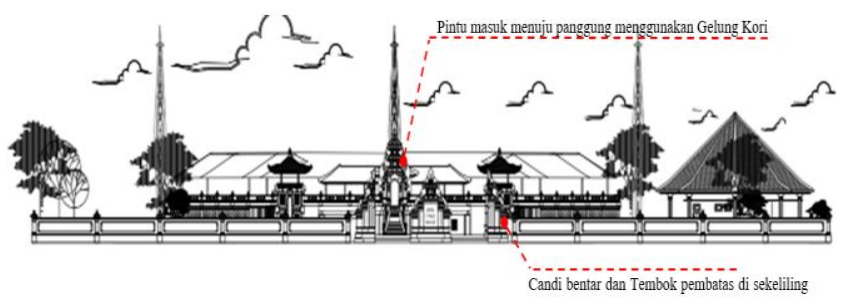

Fig. 2. Ornament

\section{Spatial Design}

The division of space in Anyar's Open Stage uses the arrangement with elements of the Tri Mandala concept as an indication of the application of Balinese Architecture. The Tri Mandala concept includes the spatial layout of Mandala, Madya Mandala and Utama Mandala. The division of the following rooms is based on activity and site noise analysis. Areas in red are high-noise zones and are public areas. The area in yellow is a noisy zone with a low category as a semipublic area and the area in green is a quiet zone as a private area and as an area for main functions ( Figure 3).

So, the element of Nista Mandala is located from the main entrance to the vehicle parking area, then the Madala Mandala element is from the drop off area and the park serves as an open space and the main element of Mandala is entering buildings.

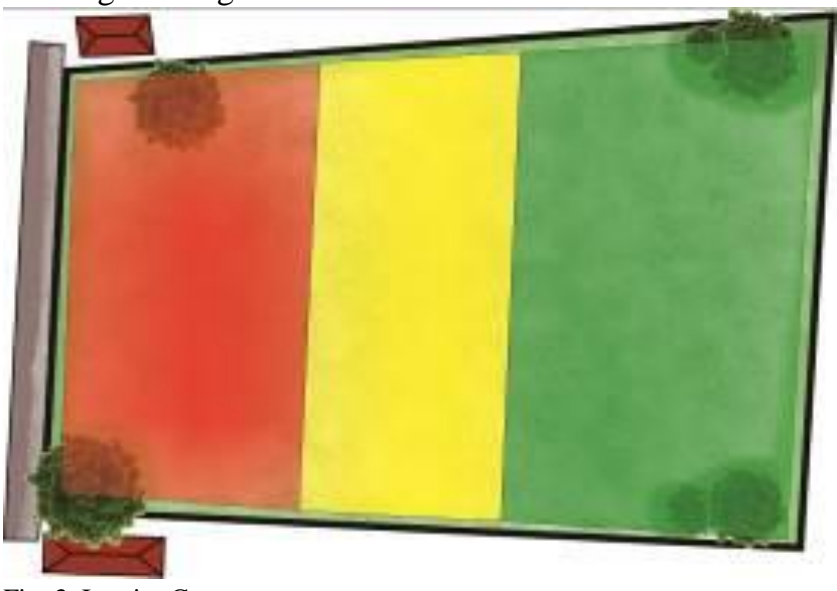

Fig. 3. Interior Concept 


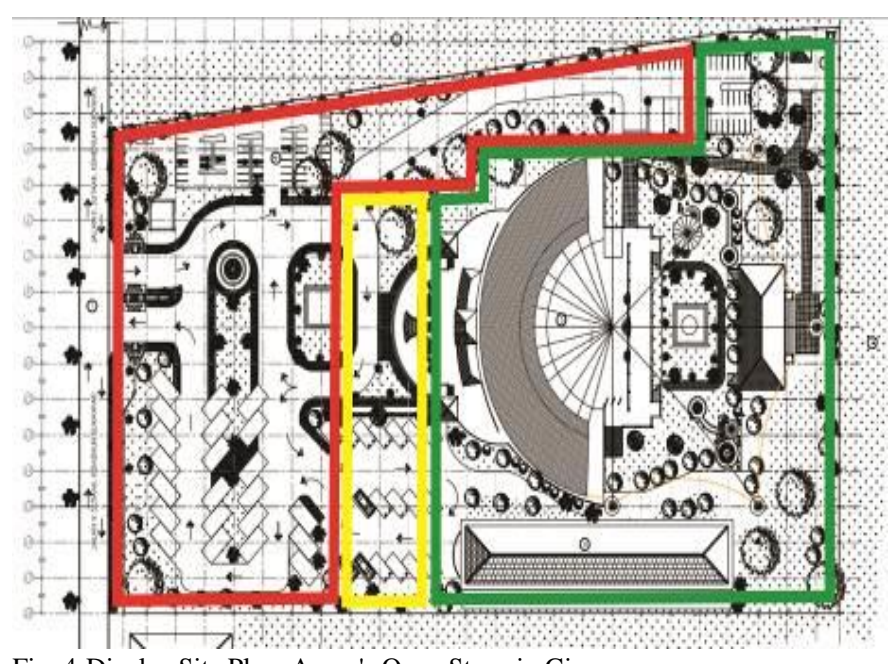

Fig. 4 Display Site Plan, Anyar's Open Stage in Gianyar

\section{Design Final}

The Open Stage building facade is dominated by the application of red brick and face material. The facade is a part of the building that usually faces the road to access the building. According to Suparno to add aesthetics in designing building facades, facade articulation needs to be added. Articulation of the facade can be created with different facade compositions through a different form or material. The building in Figure 5 is the main building where the building body is dominated by sand and red brick material. The use of red brick material and sand on the building body aims to display local local wisdom and give a natural impression that is in harmony with the surrounding environment. The head of the building (roof) uses alangalang roof coverings and the foot of the building uses natural stone. Both of these materials can create a more natural atmosphere when combined.

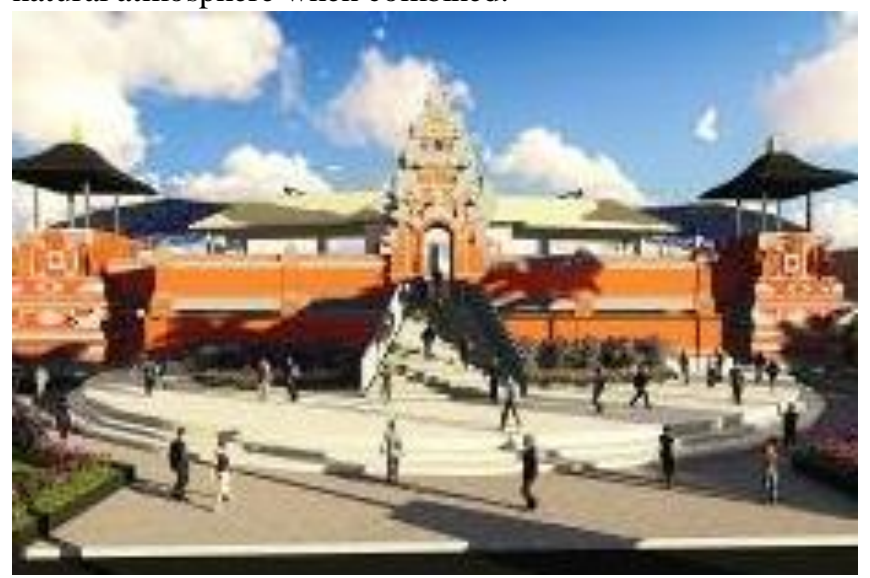

Fig. 5. Perspective

Viewed from the entrance to the site, this building is very thick with culture and impression of Balinese architecture combined with modern architecture, where the application of Balinese Architecture from the finishing element can be seen in all buildings, the use of bricks and faces is very highlighted to add to the classic atmosphere of the building alone. Similarly, the area on the stage that is made majestic with 3 grand kori with different sizes.

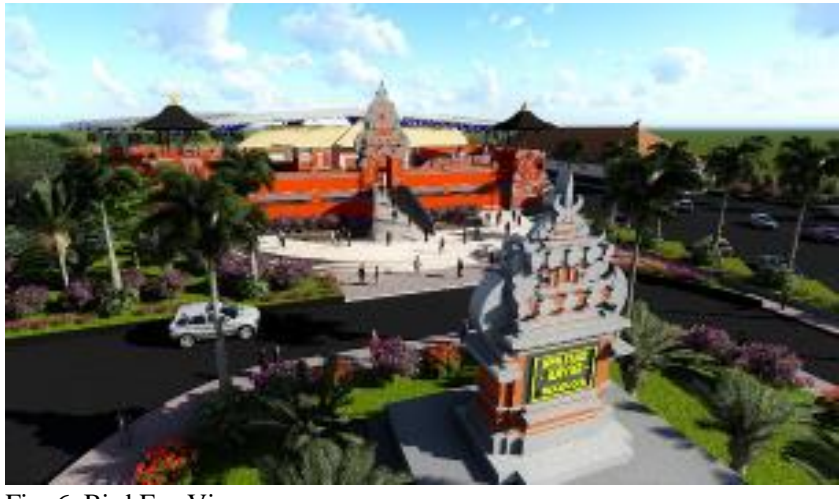

Fig. 6. Bird Eye View

\section{CONCLUSION}

Anyar Open Stage is a plan that will later be used as a container or place to accommodate various types of arts and performance activities. By seeing the number of tourists visiting Gianyar, especially to Sukawati and Ubud Districts, it is hoped that the (new) Anyar Open Stage planning in Gianyar is intended to realize or revive the interest of tourists to come back to Gianyar Regency to enjoy various types of performances, not only barong performances, but a variety of classical and modern shows with a magnificent container or venue. Anyar's Open Stage in Gianyar aims to provide a facility or facilitate activities related to traditional Balinese performing arts, modern performing arts and various types of performances related to the elements of preservation, development of interests and talents towards the beauty of Bali. Balinese carvings and ornaments are applied comprehensively in this Open Stage building, can be seen from the entrance to the site, the wall around the site, and of course in all the main buildings and supporting buildings. Spatial planning that applies the Tri Mandala element as a determinant of the nature and function of space that gave rise to the concept of Balinese Architecture. The display uses Balinese carvings on the stage and the entrance door aims to display the function of the building as a container for performances and performances of Balinese and modern culture.

The division of space in Anyar's Open Stage uses the arrangement with elements of the Tri Mandala concept as an indication of the application of Balinese Architecture. The Tri Mandala concept includes the spatial layout of Mandala, Madya Mandala and Utama Mandala. The division of the following rooms is based on activity and site noise analysis. Areas in red are high-noise zones and are public areas.

The Open Stage building facade is dominated by the application of red brick and face material. The use of red brick material and sand on the building body aims to display local local wisdom and give a natural impression that is in harmony with the surrounding environment. The head of the building (roof) uses alang-alang roof coverings and the foot of the building uses natural stone. Both of these materials can create a more natural atmosphere when combined. 
Journal of a Sustainable Global South, p-ISSN: 2579-6062

\section{REFERENCES}

[1] Bappeda Pemerintah Kabupaten Gianyar, "Rencana Tata Ruang Wilayah Kabupaten Gianyar", 2016.

[2] Dernie, David, \& Gaspari, Jacopo, "Material Imagination in Architecture", New York: Routledge, 2016 